\title{
Placental zinc in normal and intra-uterine growth-retarded pregnancies
}

\author{
BY ASHOK MALHOTRA \\ Granton Surgery, 114 Middleton Hall Road, Kings Norton, Birmingham B30 $10 J$
}

AND SUSAN J. FAIRWEATHER-TAIT*

AFRC Institute of Food Research, Colney Lane, Norwich NR4 7UA

AND P. A. WHARTON

Department of Human Nutrition, University of Glasgow, Yorkhill Hospitals, Glasgow G3 8SJ

AND H. GEE

Department of Obstetrics and Gynaecology, University of Birmingham, Birmingham B15 2TT

(Received 30 October 1989 - Accepted 24 November 1989)

\begin{abstract}
The zinc concentration of placental tissue and cord blood in sixteen mothers who gave birth to normal babies was measured. The blood volume of each placenta was estimated from measurements of haemoglobin concentration of placental homogenate and cord blood, and, by deduction, the $\mathrm{Zn}$ content of blood-free placental tissue was calculated. Results were compared with eleven mothers whose fetuses showed a low biparietal diameter velocity between 17 and 28 weeks gestation and with ten mothers who gave birth to intra-uterine growth-retarded (IUGR) babies. As expected, placental weight was significantly correlated with infant birth weight. Blood-free placental tissue contained about four times more $\mathrm{Zn}$ (approximately $10 \mu \mathrm{g} \mathrm{Zn/g}$ ) than cord blood (approximately $2.5 \mu \mathrm{g} \mathrm{Zn/ml).} \mathrm{Concentrations} \mathrm{of}$ $\mathrm{Zn}$ in blood-free placental tissue were similar in all three groups, but the cord blood $\mathrm{Zn}$ of mothers producing IUGR babies was significantly lower than that of the other two groups. Results of the present study suggested that fetal growth retardation in the mothers studied could not be explained by differences in blood-free placental $\mathrm{Zn}$ concentration, but that there may be some association between lower cord blood $\mathrm{Zn}$ levels and intra-uterine growth retardation.
\end{abstract}

Placental zinc: Pregnancy outcome: Intra-uterine growth retardation: Zinc

An inadequate supply of nutrients in pregnancy may prevent the normal growth and development of the fetus. For example, it has been widely demonstrated that a fairly marked deficiency of zinc affects growth in several species. Pups born to $\mathrm{Zn}$-deficient rats weigh significantly less than controls and have reduced skeletal growth (Hurley, 1969). In humans, $\mathrm{Zn}$ deficiency has also been reported to impair fetal growth in some studies (Jameson, 1976), but not in others (McMichael et al. 1982; Campbell-Brown et al. 1985; Tuttle et al. 1985).

An important factor which must be taken into consideration when assessing the relationship between $\mathrm{Zn}$ and fetal growth is the degree of $\mathrm{Zn}$ depletion. Experiments with rats have clearly shown that whereas severe $Z n$ deficiency unquestionably causes gross reduction in fetal growth, diets that are only just suboptimal with respect to $\mathrm{Zn}$ may, in fact, enhance fetal growth (Fairweather-Tait et al. 1985). In Britain, marginal $\mathrm{Zn}$ deficiency is a more likely possibility in pregnant women than severe $\mathrm{Zn}$ deficiency.

\footnotetext{
* For reprints.
} 
In many studies $\mathrm{Zn}$ deficiency is diagnosed using maternal plasma or serum $\mathrm{Zn}$ levels. However, these are not generally considered to be a sensitive index of total body $\mathrm{Zn}$ status (Fairweather-Tait, 1988). Furthermore, the true relationship between maternal $\mathrm{Zn}$ status and that of the fetus cannot be determined accurately as it would require measurements of $\mathrm{Zn}$ in the developing infant. A good alternative is the placenta since this is the tissue involved with supplying nutrition to the fetus. It is peculiar to pregnancy, forms and develops after conception and is enzyme-rich, situated at the interface between mother and baby. During its normal growth it is in dynamic equilibrium with the surrounding blood, and with a total lifetime of several months, we believe it reflects an average exposure to particular nutrients like $\mathrm{Zn}$, carried in the maternal blood, which are in turn supplied to the growing fetus. The present investigation was designed to investigate the relationship between $\mathrm{Zn}$ and fetal growth.

\section{EXPER IMENT A L \\ Patients and methods}

All mothers referred to the antenatal clinic before 17 weeks gestation were invited to attend at 17 weeks and again at 28 weeks for detailed assessment. They were selected and allocated to one of three groups in the study.

Normal control group. These patients were considered to be at low risk of having a smallfor-date baby, according to the following assessments made at 28 weeks gestation: (a) diastolic blood pressure $>90 \mathrm{~mm}$ mercury, i.e. normotensive; (b) fasting glucose ( $8 \mathrm{~h}$ or more) 4-4.9 mmol/1 (15th-97th centiles of the study population); (c) body-weight $<85 \mathrm{~kg}$ ( $<90$ th centile of the study population); (d) normal increment of triceps skinfold thickness $>3 \mu \mathrm{m} / \mathrm{d}$ ( $>10$ th centile of the study population; Viegas et al. 1987); (e) increment in fetal biparietal diameter velocity from 17 to 28 weeks of gestation of $390-498 \mu \mathrm{m} / \mathrm{d}$ (10th centile to mean +2 SD of the study population).

Due to limited resources it was not possible to analyse the placentas of all the control mothers. Therefore a subgroup was selected as follows: (a) where a dietary assessment had been made at 28 weeks, (b) delivery between thirty-seven and forty-one completed weeks; (c) corrected birth weight between the 10th and 90th centiles (Thompson et al. 1968; Altman \& Coles, 1980). A total of sixteen patients fulfilled these criteria, for whom placental $\mathrm{Zn}$ assays were performed.

Low biparietal diameter ( $B P D$ ) velocity group. These patients had a BPD velocity between 17 and 28 weeks of $<390 \mu \mathrm{m} / \mathrm{d}$ ( $<10$ th centile of the study population). Apart from a reduced BPD velocity, they fulfilled all the other criteria of normality at the screening clinic defined previously. There were fourteen patients in this group, eleven of whom had placental $\mathrm{Zn}$ assays carried out.

Intra-uterine growth-retarded (IUGR) group. These patients were originally included in the control group described previously, i.e. were normal at the 28 -week screening clinic in terms of fulfilling the previously defined criteria $(\mathrm{a}-\mathrm{d})$, but at delivery produced babies with a corrected birth weight below the 10th centile (Thompson et al. 1968; Altman \& Coles, 1980). Ten of the thirteen mothers who were assigned to this group had placental $\mathrm{Zn}$ assays carried out.

\section{Clinic assessment}

All mothers attended the antenatal clinic at 17 and 28 weeks of pregnancy for a routine obstetric assessment including a fetal biparietal diameter (measured by ultrasound using a system XL2 scanner; Dynamic Imaging Ltd, Livingston, Scotland) and maternal anthropometry, namely weight (Salter spring), height (Seca metal gauge; Seca, Hamburg, 
W. Germany) and triceps skinfold thickness (Holtain skinfold calliper; Holtain Ltd, Crosswell, Dyfed). All measurements were carried out by the same operator. The ultrasound scanner had a freeze frame, scale expansion, inbuilt photography unit, and linear and circumferential computerized measurements. The biparietal diameter was measured from the outer echo of one parietal bone to the inner edge of the other parietal bone of the fetal skull. The long axis was determined by locating the midline echo from the falx cerebri, taking into account the attitude of the head. Three consistent readings were taken at each scan. The BPD velocity $(\mu \mathrm{m} / \mathrm{d})$ was calculated for each mother by the formula (BPD at 28 weeks - BPD at 17 weeks)/time-period (d).

At 28 weeks a blood sample was taken from as many subjects as possible and fasting $(>8 \mathrm{~h}$ ) plasma $\mathrm{Zn}$ was estimated. This was performed by removing a small volume of plasma, deproteinizing with trichloroacetic acid $(1: 3, \mathrm{v} / \mathrm{v})$ and the $\mathrm{Zn}$ concentration measured by atomic absorption spectroscopy (AAS), as described below.

\section{Dietary assessment}

Women were interviewed between 28 and 30 weeks of pregnancy by a dietitian. They were all asked to recall their food intake for the $24 \mathrm{~h}$ ending at midnight on the previous day and these results are presented. The exact dietary recall method has been described previously (Eaton et al. 1984). Nutrient intakes were calculated from the $24 \mathrm{~h}$ recall using the food tables of Paul \& Southgate (1978) on a computer program at the Dunn Nutritional Laboratory, Cambridge.

\section{Measurements after delivery}

At birth, babies were cleaned and weighed naked to the nearest $10 \mathrm{~g}$ on a spring balance (Howard) and placentas to the nearest $1 \mathrm{~g}$ on an Avery balance by the midwife responsible for the delivery. The same balances were used throughout the study. At $12-48 \mathrm{~h}$ after birth the following additional measurements were made: crown-heel length measured with a neonatometer (Holtain Ltd), mid-biceps and mid-triceps skinfold thickness with a Holtain calliper and mid-upper-arm circumference of the right arm with a paper tape measure. Gestational age was calculated from the mother's last menstrual period and confirmed by ultrasound. If there was a discrepancy of more than 1 week with the ultrasound reading, then the ultrasound dates were taken. Birth weights were also expressed as a standard deviation score for gestation (Thompson et al. 1968; Altman \& Coles, 1980).

\section{Analytical procedures}

Collection of placentas. At delivery the placenta was weighed and sealed in a plastic bag and placed in a refrigerator at $4^{\circ}$. Within $12 \mathrm{~h}$ it was transferred for storage at $-18^{\circ}$ until analysed.

Estimation of blood-free tissue in placenta. Each placenta was thawed, weighed and homogenized in a stainless-steel commercial Waring blender (Jennings, Nottingham) with an equal weight of distilled water. Subsamples of the homogenate were taken and duplicate $12 \mathrm{ml}$ portions centrifuged in calibrated plastic tubes at $2000 \mathrm{~g}$ for $15 \mathrm{~min}$. The proportion of liquid to tissue was measured and the haemoglobin concentration of the supernatant fraction determined using the cyanomethaemoglobin method. The haemoglobin level of cord blood was also determined on a sample of blood collected at delivery, and from these the blood volume and, hence, by deduction the weight of blood-free tissue in the placenta was calculated.

$\mathrm{Zn}$ analysis. Duplicate samples of cord blood (2-3 g) and placental homogenate (8-10 g) were heated at $100^{\circ}$ for $10 \mathrm{~min}$ with $10 \mathrm{ml}$ concentrated nitric acid (Analar). A few drops of hydrogen peroxide were added to complete the digestion and the solution was then made 
Table 1. Details of mothers in normal, low biparietal diameter (BPD) velocity and intra-uterine growth-retarded (IUGR) groups*

(Mean values and standard deviations)

\begin{tabular}{|c|c|c|c|c|c|c|c|}
\hline \multirow[t]{2}{*}{ Group ... } & \multicolumn{2}{|c|}{ Normal ( $n$ 16) } & \multicolumn{2}{|c|}{$\begin{array}{c}\text { Low BPD } \\
\text { velocity }(n 11)\end{array}$} & \multicolumn{2}{|c|}{ IUGR $(n 10)$} & \multirow[b]{2}{*}{ RMS } \\
\hline & Mean & SD & Mean & $\mathrm{SD}$ & Mean & SD & \\
\hline Age (years) & $24 \cdot 9$ & 一 & $25 \cdot 1$ & - & $27 \cdot 0$ & - & - \\
\hline Height (m) & 1.61 & 0.06 & $1 \cdot 60$ & 0.07 & $1 \cdot 60$ & 0.05 & - \\
\hline $\begin{array}{l}\text { Wt gain between } \\
16 \text { and } 28 \text { weeks } \\
\text { gestation }(\mathrm{kg} / \text { week })\end{array}$ & $0 \cdot 604^{\mathrm{a}}$ & - & $0.570^{\mathrm{a}}$ & - & $0.405^{b}$ & - & 0.029 \\
\hline $\begin{array}{l}\text { Wt at } 28 \text { weeks } \\
\text { gestation }\end{array}$ & $70 \cdot 0^{\mathrm{a}}$ & $10 \cdot 3$ & $64 \cdot 9^{\mathrm{a}}$ & $5 \cdot 0$ & $59 \cdot 8^{\mathrm{b}}$ & $5 \cdot 2$ & - \\
\hline $\begin{array}{l}\text { Plasma zinc at } 28 \text { weeks } \\
\text { gestation }(\mu \mathrm{g} / \mathrm{ml})\end{array}$ & $0.84(n 15)$ & - & $0.88(n 8)$ & - & $0.97(n 5)$ & - & 0.06 \\
\hline
\end{tabular}

RMS, residual mean square.

a.b Values with different superscript letters in each horizontal line were significantly different $(P<0 \cdot 05)$.

* For details of criteria for groups, see p. 614 .

up to an appropriate volume with distilled water. The $\mathrm{Zn}$ concentration was determined by AAS (PU 9000; Pye Unicam, Cambridge) using bovine liver as a reference standard (National Bureau of Standards, Gaithersburg, USA).

\section{Statistical analysis}

Differences between the three groups were tested using one-way analysis of variance (ANOVA). Results are presented as means and the residual mean square (RMS), where the standard error of the difference (SED) between means is equal to RMS $\left(1 / n_{1},+1 / n_{2}\right)$. Where there was a significant effect, approximate $t$ tests were performed where $t=\left(\operatorname{mean}_{1}\right.$ - mean $\left._{2}\right) / \mathrm{SED}$, with residual degrees of freedom. In the case of unequal variances a modified ANOVA program was used and standard deviations for each group are presented. The relationship between the birth weight of the baby and cord blood $\mathrm{Zn}$ and the $\mathrm{Zn}$ content of placental tissue was examined in each of the three groups by regression analysis.

\section{RESULTS}

Details of the mothers studied are presented in Table 1. There were no significant differences between the three groups in maternal age, height, or fasting plasma $\mathrm{Zn}$ measured at 28 weeks gestation. Mothers who fell into the IUGR group had a reduced weight velocity between 16 and 28 weeks, resulting in a lower weight at 28 weeks.

There did not appear to be a substantial difference in smoking or alcohol consumption between the three groups. In the normal group four mothers smoked (ten, ten, fifteen and twenty cigarettes/d) and one consumed 6 units alcohol/week. In the low BPD velocity group three mothers smoked (eight, ten and twelve cigarettes/d) and one consumed 16 units alcohol/week. In the IUGR group three mothers smoked (fifteen, twenty and thirty cigarettes/d) and two consumed alcohol ( 2 and 20 units/week).

It had not been possible to assess the food intakes of all mothers in the present study, and although dietary intake measurement was one criterion for selecting control mothers, only five of the low BPD velocity group and three of the IUGR group had been interviewed. Values for food intake are illustrated in Fig. 1. The three mothers in the IUGR 

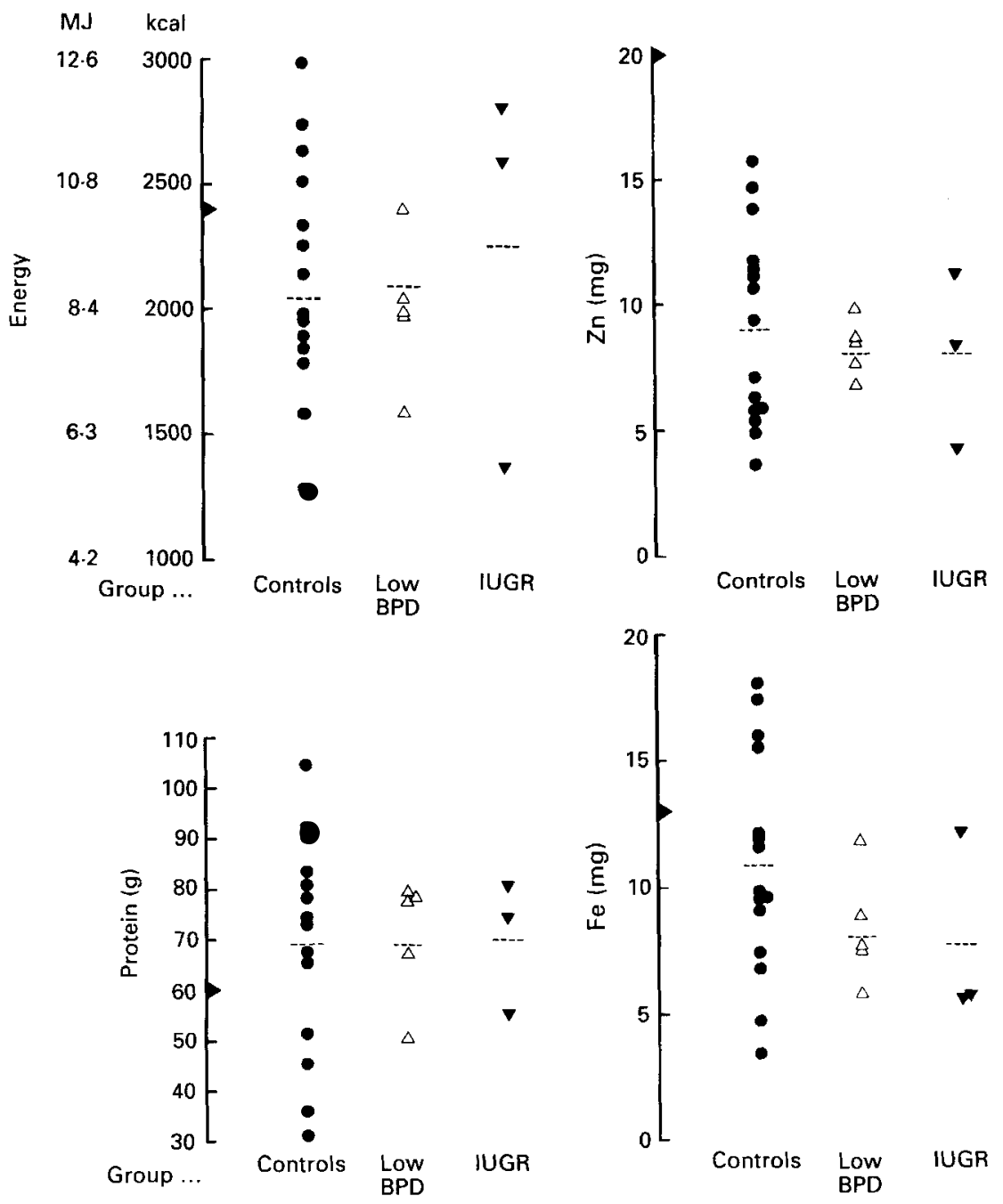

Fig. 1. Daily intakes ( $24 \mathrm{~h}$ recall) of energy, protein, zinc and iron by women at 28 weeks of pregnancy; (O) normal controls, $(\triangle)$ low biparietal diameter (BPD) velocity group, $(\nabla)$ intra-uterine growth-retarded (IUGR) group. Individual results are presented together with group means (-- - ). ( $>$ ) Recommended daily amount of energy, protein and Fe for pregnant women in the UK (Department of Health and Social Security, 1979) and recommended daily allowance for $\mathrm{Zn}$ in pregnant women in the USA (Committee on Dietary Allowance, Food and Nutrition Board, National Rescarch Council, 1980). For details of criteria for groups, see p. 614.

group did not appear to consume less energy, protein, Zn or iron than mothers in the other two groups. Previous work (Eaton et al. 1984) has shown that results obtained by recall methods tend to be a little below those obtained by weighed methods. Nevertheless, all means for energy and Fe were less than the UK recommended daily amount for pregnant women (Department of Health and Social Security, 1979) and the means for Zn were less than the USA recommended daily allowance (Committee on Dietary Allowances, Food and Nutrition Board, National Research Council, 1980).

By the very nature of the grouping of the subjects there were significant differences in the outcome of pregnancy, as shown in Table 2, which could not be explained in terms of length 
Table 2. Details of babies in normal, low biparietal diameter $(B P D)$ velocity and intra-uterine growth-retarded (IUGR) groups*

(Values are means for no. of subjects indicated)

\begin{tabular}{|c|c|c|c|c|}
\hline Group ... & $\begin{array}{c}\text { Normal } \\
(n 16)\end{array}$ & $\begin{array}{c}\text { Low BPD } \\
\text { velocity } \\
\left(\begin{array}{lll}n & 11\end{array}\right)\end{array}$ & $\begin{array}{c}\text { IUGR } \\
(n 10)\end{array}$ & RMS \\
\hline BPD velocity $16-28$ weeks $(\mu \mathrm{m} / \mathrm{d})$ & $446 \cdot 6^{\mathrm{a}}$ & $377 \cdot 7^{\mathrm{b}}$ & $441 \cdot 0^{\mathrm{a}}$ & $409 \cdot 5$ \\
\hline Gestation (weeks) & $40 \cdot 2$ & $39 \cdot 4$ & $38 \cdot 6$ & $2 \cdot 0$ \\
\hline Birth wt $(\mathrm{kg})$ & $3 \cdot 47^{\mathrm{a}}$ & $3.09^{\circ}$ & $2.53^{\mathrm{c}}$ & $100 \cdot 3$ \\
\hline Head circumference (mm) & $350^{2}$ & $341^{\mathrm{b}}$ & $331^{\circ}$ & 6.0 \\
\hline Length (mm) & $508^{\mathrm{a}}$ & $494^{\mathrm{a}}$ & $476^{b}$ & 35 \\
\hline Biceps skinfold thickness (mm) & $3.01^{\mathrm{a}}$ & $2 \cdot 70^{\mathrm{b}}$ & $2 \cdot 42^{\mathrm{b}}$ & 0.11 \\
\hline Triceps skinfold thickness (mm) & $3 \cdot 60^{\mathrm{a}}$ & $3 \cdot 26^{\mathrm{a}}$ & $2 \cdot 60^{\mathrm{b}}$ & $0 \cdot 27$ \\
\hline
\end{tabular}

RMS, residual mean square.

a,b,c Values with different superscript letters in each horizontal line were significantly different $(P<0 \cdot 05)$.

* For details of criteria for groups, see p. 614.

Table 3. Placental measurements in normal, low biparietal diameter (BPD) velocity and intra-uterine growth-retarded (IUGR) groups*

(Mean values and standard deviations)

\begin{tabular}{|c|c|c|c|c|c|c|c|}
\hline \multirow[t]{2}{*}{ Group ... } & \multicolumn{2}{|c|}{ Normal ( $n$ 16) } & \multicolumn{2}{|c|}{$\begin{array}{l}\text { Low BPD velocity } \\
(n-1)\end{array}$} & \multicolumn{2}{|c|}{ IUGR ( $n$ 10) } & \multirow[b]{2}{*}{ RMS } \\
\hline & Mean & SD & Mean & SD & Mean & $\mathrm{SD}$ & \\
\hline Placental wt (g) & $682^{\mathrm{a}}$ & 157 & $595^{\mathrm{a}}$ & 131 & $473^{\mathrm{b}}$ & 61 & - \\
\hline Placental wt: birth wt & $0 \cdot 169$ & - & 0.169 & - & 0.157 & - & 0.001 \\
\hline $\begin{array}{l}Z n \text { concentration } \\
\text { of placenta }(\mu \mathrm{g} / \mathrm{g})\end{array}$ & $7 \cdot 71$ & $1 \cdot 01$ & $7 \cdot 70$ & 0.70 & $7 \cdot 14$ & $0 \cdot 68$ & - \\
\hline Cord blood $\mathrm{Hb}(\mathrm{g} / \mathrm{l})$ & 160 & - & 148 & - & 155 & - & 60 \\
\hline Cord blood zinc $(\mu \mathrm{g} / \mathrm{ml})$ & $2 \cdot 4^{\mathrm{a}}$ & 0.4 & $2 \cdot 6^{\mathrm{ab}}$ & $1 \cdot 3$ & $2 \cdot 0^{b}$ & $0 \cdot 3$ & - \\
\hline $\begin{array}{l}\text { Blood-free (BF) } \\
\text { placental wt (g) }\end{array}$ & $453^{\mathrm{a}}$ & - & $413^{\mathrm{a}}$ & - & $302^{\mathrm{b}}$ & - & 5665 \\
\hline $\begin{array}{l}\mathrm{Zn} \text { concentration of } \\
\mathrm{BF} \text { placenta }(\mu \mathrm{g} / \mathrm{g})\end{array}$ & $10 \cdot 33$ & - & $9 \cdot 87$ & - & $10 \cdot 16$ & - & $1 \cdot 41$ \\
\hline $\begin{array}{l}\text { Total } \mathrm{Zn} \text { content of } \\
\text { BF placenta }(\mathrm{mg})\end{array}$ & $4 \cdot 64^{2}$ & 0.89 & $4 \cdot 08^{2}$ & 0.72 & $303^{\circ}$ & $0 \cdot 33$ & - \\
\hline $\begin{array}{l}\text { Total } \mathrm{Zn} \text { in } \\
\text { placenta }(\mathrm{mg})\end{array}$ & $5 \cdot 19^{a}$ & $1 \cdot 02$ & $4 \cdot 55^{\mathrm{a}}$ & 0.92 & $3 \cdot 36^{\mathrm{b}}$ & $0 \cdot 40$ & - \\
\hline
\end{tabular}

RMS, residual mean square; $\mathbf{H b}$, haemoglobin.

${ }^{\mathrm{a}, \mathrm{b}}$ Values with different superscript letters in each horizontal line were significantly different $(P<0 \cdot 05)$.

* For details of criteria for groups, see p. 614

of gestation. Babies born to the low BPD velocity group had a reduced BPD velocity, but in all other aspects they were similar to the control group. However, babies born to mothers in the IUGR group weighed less, were shorter, and had reduced head circumference, and biceps and triceps skinfold thicknesses.

The placentas from mothers with IUGR babies were significantly smaller than either the normal or low BPD velocity groups, as shown in Table 3, but when expressed as a proportion of birth weight, there were no differences between the groups. The cord blood haemoglobin concentrations were similar but the $\mathrm{Zn}$ levels appeared to be slightly lower in 
the IUGR group. When the calculated blood volume for each placenta was deducted from the weight recorded at delivery, the blood-free placental tissue again weighed less in the IUGR group.

The total $\mathrm{Zn}$ in the placenta was lower in the IUGR group, although the $\mathrm{Zn}$ concentration of placental tissue did not differ from the other two groups. There was a significant relationship between the total placental $\mathrm{Zn}$ level and birth weight of the infant ( $R 0.78, P<0.001$ ). When the $\mathrm{Zn}$ contributed by blood was deducted, similar results were found in blood-free placental tissue, i.e. no differences in $\mathrm{Zn}$ concentration. The fact that total $\mathrm{Zn}$ was significantly lower in the IUGR group, probably relates to differences in placental weight.

\section{DISCUSSION}

The dependence of fetal growth on adequate $\mathrm{Zn}$ supply via the placental tissue is indisputable. However, the required level of $\mathrm{Zn}$ which can be deemed 'adequate' has not yet been agreed, mainly because there is no good means of assessing the $\mathrm{Zn}$ status of mother and neonate. Nevertheless, a number of studies have been carried out investigating the relationship between maternal $\mathrm{Zn}$ nutrition and infant birth weight.

Various estimates have been made of $\mathrm{Zn}$ intake during pregnancy. Hambidge et al. (1983) used a $24 \mathrm{~h}$ record technique at each month of gestation and found the mean intake to be about $11 \mathrm{mg} \mathrm{Zn/d}$. This did not change significantly at any stage of pregnancy. Simmer et al. (1987) found the $\mathrm{Zn}$ intake during the last trimester of mothers who produced IUGR babies to be less than mothers with normal-weight babies, i.e. 11.3 and $13.0 \mathrm{mg} / \mathrm{d}$ respectively. This was assessed from a $7 \mathrm{~d}$ diet history. A more precise estimate of $\mathrm{Zn}$ intake is the weighed-intake method, as used by Tuttle et al. (1985) in pregnant women in Scotland during the 30th week of gestation. Mean $\mathrm{Zn}$ intake of healthy mothers was $9 \cdot 1 \mathrm{mg} / \mathrm{d}$ and of mothers at risk of delivering a growth-retarded baby was $9.4 \mathrm{mg} / \mathrm{d}$. The dietary information presented in the present study is limited but $\mathrm{Zn}$ intakes were not dissimilar to those found by Tuttle et al. (1985), and did not show large variations between the three groups.

The results from previous studies on the relationship between $\mathrm{Zn}$ and intra-uterine growth are controversial. The major problem with such work is the lack of a suitable means of monitoring $\mathrm{Zn}$ status during pregnancy. Plasma $\mathrm{Zn}$ is often used, and McMichael et al. (1982) showed no difference between mid-pregnancy maternal serum $\mathrm{Zn}$ in IUGR and normal groups, which were 0.77 and $0.73 \mu \mathrm{g} / \mathrm{ml}$ respectively. Our findings also showed no difference. Mean plasma $\mathrm{Zn}$ values at 28 weeks were $0.84,0.88$, and $0.97 \mu \mathrm{g} / \mathrm{ml}$ in normal, low BPD velocity and IUGR groups respectively.

Cord blood $\mathrm{Zn}$ was found to be slightly reduced $(P<0.05)$ in mothers giving birth to IUGR babies. There was, however, no correlation between birth weight and cord blood $\mathrm{Zn}$ when the values for all the mothers were examined. This agrees with the study of Bogden et al. (1978) in which maternal plasma and cord blood plasma $\mathrm{Zn}$ levels were measured in normal- and low-birth-weight groups. When critically examining values for maternal and cord blood, it is important to remember that maternal serum $\mathrm{Zn}$ levels may be the outcome, rather than a determinant, of fetal growth in pregnancy. The $\mathrm{Zn}$ content of cord blood represents only one point in time and is, therefore, not necessarily representative of the situation throughout the 40 -week gestational period.

An alternative approach to investigate the relationship between $\mathrm{Zn}$ and fetal growth is to study the placenta. Blood-free placental tissue reflects the long-term accumulation of $\mathrm{Zn}$ in the body as opposed to instantaneous measurements when blood is assayed. Ward et al. (1987) measured placental levels of a large number of elements, including $\mathrm{Zn}$, in an attempt to correlate the concentration of each with birth weight. Mothers with babies weighing 
$>3000 \mathrm{~g}$ at birth had mean placental $\mathrm{Zn}$ concentrations of $52 \mu \mathrm{g} / \mathrm{g}$ dry weight, compared with $40.6 \mu \mathrm{g} / \mathrm{g}$ dry weight for those with babies weighing $<3000 \mathrm{~g}$. The wet weight: dry weight ratios are not given, but assuming that the water content of whole placental tissue is $83 \%$ (Lentner, 1984), these values translate to 8.8 and $6.9 \mu \mathrm{g} / \mathrm{g}$ wet weight respectively. The values for whole placental tissue in the present study (Table 3) were 7.7, 7.7, and $7 \cdot 1 \mu \mathrm{g} / \mathrm{g}$ wet weight in normal, low BPD velocity and IUGR groups respectively. Although lower, the values for the IUGR group were not significantly different from the controls. When the contribution made by blood is deducted, the concentrations rose to $10 \cdot 3,9 \cdot 9$ and $10 \cdot 2 \mu \mathrm{g} / \mathrm{g}$ blood-free placental tissue respectively. Again there were no significant differences between the groups. Thus, the fact that total placental $\mathrm{Zn}$ was lower in the IUGR group reflects the differing placental weights rather than any fundamental difference in $\mathrm{Zn}$ content. The results of the present study show that the $\mathrm{Zn}$ concentration of placental tissue is about four times that of whole cord blood. Although little is known about the transport of $\mathrm{Zn}$ in the placenta, one study with guinea-pigs suggests active uptake at the maternal surface combined with a slow release into the fetus, down a concentration gradient (Simmer $e t a l .1985$ ). The fact that blood-free placental tissue is relatively rich in $\mathrm{Zn}$, even in placentas from mothers giving birth to IUGR babies, indicates that there is a sizeable pool of $\mathrm{Zn}$, but it is not known whether or not this $\mathrm{Zn}$ is available to the fetus.

The results of the present study would suggest that placental $\mathrm{Zn}$ concentrations are not related to decreased BPD velocity or IUGR in the fetus. However, an adequate daily supply of $\mathrm{Zn}$ to the fetus throughout the total gestational period is a crucial factor in determining fetal nutrition and the outcome of pregnancy. The observation that cord blood $\mathrm{Zn}$ concentrations in mothers giving birth to IUGR babies were lower than controls may be a significant finding that warrants further research. At present there is not enough information in the literature to judge whether or not the placental $\mathrm{Zn}$ concentrations fell into the 'normal' range. Despite the fact that mothers in the present study had fairly low estimated $\mathrm{Zn}$ intakes of $8-9 \mathrm{mg} / \mathrm{d}$, the lack of correlation between placental $\mathrm{Zn}$ levels and birth weight would suggest that the dietary $\mathrm{Zn}$ was adequate. Apart from the small difference in cord blood $\mathrm{Zn}$ concentrations, the results of the present study provide no real justification for the routine administration of $\mathrm{Zn}$ supplements to pregnant women in order to improve fetal growth or pregnancy outcome.

The authors would like to thank Professor B. A. Wharton for invaluable advice and help in organizing the project, Mrs Zoe Piper for skilled technical assistance, and Mr P. G. Needham, Mr J. R. Pogmore and Mr J. Cruickshank for allowing us to study their patients. They are grateful to the nursing and other staff at Sorrento Maternity Hospital for their help.

\section{REFERENCES}

Altman, D. G. \& Coles, E. C. (1980). Normograms for precise determination of birth weight for dates. British Journal of Obstetrics and Gynaecology 87, 81-86.

Bogden, J. D., Thind, I. S., Kemp, F. W. \& Caterini, H. (1978). Plasma concentrations of calcium, chromium, copper, iron, magnesium, and zinc in maternal and cord blood and their relationship to low birth weight. Journal of Laboratory and Clinical Medicine 92, 455-462.

Campbell-Brown, M., Ward, R. J., Haines, A. P., North, W. R. S., Abraham, R., McFadyen, I. R. \& Turnland, J. R. (1985). Zinc and copper in Asian pregnancies - is there evidence for a nutritional deficiency? British Journal of Obstetrics and Gynaecology 92, 875-885.

Committee on Dietary Allowances, Food and Nutrition Board, National Research Council (1980). Recommended Dietary Allowances, 9th ed. Washington, DC: National Academy Press.

Department of Health and Social Security (1979). Recommended daily amounts of food energy and nutrients for groups of people in the United Kingdom. Report on Health and Social Subjects no. 15. London: H.M. Stationery Office. 
Eaton, P. M., Wharton, P. A. \& Wharton, B. A. (1984). Nutrient intake of pregnant Asian women. British Journal of Nutrition 52, $457-468$.

Fairweather-Tait, S. J. (1988). Zinc in human nutrition. Nutrition Research Reviews 1, 23-38.

Fairweather-Tait, S. J., Wright, A. J. A., Cooke, J. \& Franklin, J. (1985). Studies of zinc metabolism in pregnant and lactating rats. British Journal of Nutrition 54, 401-413.

Hambidge, K. M., Krebs, N. F., Jacobs, M. A., Favier, A., Guyette, L. \& Ikle, D. N. (1983). Zinc nutritional status during pregnancy: a longitudinal study. American Journal of Clinical Nutrition 37, 429-442.

Hurley, L. S. (1969). Zinc deficiency in the developing rat. American Journal of Clinical Nutrition 22, $1332-1339$.

Lentner, C. [editor]. (1984). Geigy Scientific Tables, vol. 3, p. 291. Basle: Ciba-Geigy.

Jameson, S. (1976). Effects of zinc deficiency in human reproduction. Acta Medica Scandinavica 593, Suppl., 1-89

McMichael, A. J., Dreosti, I. E., Gibson, G. T., Hartshorne, J. M., Buckley, R. A. \& Colley, D. P. (1982). A prospective study of serial maternal serum zinc levels and pregnancy outcome. Early Human Development 7 , 59-69.

Paul, A. A. \& Southgate, D. A. T. (1978). McCance and Widdowson's The Composition of Foods. London: H.M. Stationery Office.

Simmer, K., Dwight, J. St. J., Brown, I. M. H., Thompson, R. P. H. \& Young, M. (1985). Placental handling of zinc in the guinea pig. Biology of the Neonate 48, 114-121.

Simmer, K., Iles, C. A., Slavin, B., Keeling, P. W. N. \& Thompson, R. P. H. (1987). Maternal nutrition and intrauterine growth retardation. Human Nutrition: Clinical Nutrition 41C, 193-197.

Thompson, A. M., Billewicz, W. Z. \& Hytten, F. E. (1968). The assessment of fetal growth. Journal of Obstetrics and Gynaecology of the British Commonwealth 75, 903-916.

Tuttle, S., Aggett, P. J., Campbell, D. \& MacGillivray, 1. (1985). Zinc and copper nutrition in human pregnancy: a longitudinal study in normal primigravidae and in primigravidae at risk of delivering a growth retarded baby. American Journal of Clinical Nutrition 41, 1032 1041.

Viegas, O. A. C., Cole, T. J. \& Wharton B. A. (1987). Impaired fat deposition in pregnancy: an indicator for nutritional intervention. American Journal of Clinical Nutrition 45, 23-28.

Ward, N. I., Watson, R. \& Bryce-Smith, D. (1987). Placental element levels in relation to fetal development for obstetrically 'normal' births: a study of 37 elements. Evidence for effects of cadmium, lead and zinc on fetal growth, and for smoking as a source of cadmium. International Journal of Biosocial Research 9, 63-81. 